\title{
KESENIAN CHING PHO LING DI DAERAH PURWOREJO JAWA TENGAH CERMINAN BUDAYA PISOWANAN
}

\begin{abstract}
Nanik Sri Prihatini ${ }^{1}$
Abstrct : pisowanan in the perfomance of Ching Pho Ling, is a phenomenon sosio-kultural that is a demang report duty in its power region. To do the pisowanan, demang followed by the guard to show the spirit of pregnant patriotism assess the struggle, faithfulness, independence, togetherness, and others. In pisowanan of is in form of pageant carry arms to keep safety. Besides also simple music to eliminate tired during of journey. From the pageant form become the artistic idea source of performance in the functioning Ching Pho Ling as look oning/ entertainment amusement society. Creativity of there are at development move the, accompaniment and its cloth. This artistry is very concerning because omiting the single exist in Regency Purworejo, but still eksis. So that require to get the serious attention from local government.
\end{abstract}

Key words: pisowanan, demang, pageant

Purworejo secara administrasi merupakan salah satu daerah kabupaten di Propinsi Jawa Tengah bagian selatan. Kabupaten Purworejo menurut Koentjaraningrat termasuk ke dalam wilayah budaya Bagelen yang kaya dengan seni pertunjukan rakyat. Bagelen pada abad XVIII menjadi wilayah Mataram yang disebut wilayah Negaragung, daerah inti kerajaan yang langsung diperintah dari pusat kerajaan (Djuliati, 2000:12). Kekayaan seni pertujukan rakyat di daerah Bagelen ditandai dengan adanya berbagai bentuk seni pertunjukan yang masih hidup dan berkembang di daerah tersebut. Setidaknya ada kurang lebih 30 bentuk seni pertunjukan rakyat yang berupa tari, musik dan teater.

Dilihat dari bentuk pertunjukannya, seni pertunjukan rakyat di daerah Purworejo nampaknya dilatarbelakangi oleh kondisi dan fenomena setempat yang pernah terjadi pada masa lalu. Dengan kata lain bahwa kesenian rakyat yang hidup dan berkembang di daerah Purworejo merupakan representasi atau pengungkapan peristiwa masa lalu ke dalam suatu wujud kesenian. Peristiwa masa lalu yang pernah terjadi di daerah Purworejo di

${ }^{1}$ Nanik Sri Prihatini adalah Dosen Jurusan Tari dan pada Program Pascasarjana ISI Surakarta. 
antaranya pada masa terjadinya perang Dipanegara melawan kolonial pada tahun 1825-1830, pengaruh kekuasaan kerajaan Mataram Baru dan masuknya agama Islam. Realitas tersebut digarisbawahi oleh Sedyawati (1995: 1), di antaranya bahwa bentuk seni pertunjukan yang membawa pesan ke-Islam an telah berlangsung turun-menurun dan mempunyai masyarakat pendukung di tiap-tiap daerahnya. Nuansa ke-Islam-an tercermin dengan digunakannya instrumen terbang (rebana), jidur atau bedug kecil dan lagu-lagu yang disajikan dengan bahasa Arab. Pengaruh perang Dipanegara tercermin pada tema keprajuritan serta bentuk sajian dengan pola lantai berbaris, gerak, busana, dan peralatan tari yang digunakan. Seni pertunjukan rakyat yang berkembang di daerah ini pada umumnya disajikan secara kelompok dan hampir semuanya menggunakan pola lantai berbaris.

Ada sembilan bentuk seni pertunjukan rakyat yang sampai sekarang masih hidup dan berkembang di daerah Purworejo, adalah: Dolalak, Ching Pho Ling, Kobrosiswa, Kuda Kepang, Kuntulan, Madya Pitutur, Samanan, Kemprang, dan Slawatan. Dari bentuk-bentuk yang telah disebutkan, Dolalak merupakan salah satunya yang paling berkembang, kondisi ini ditandai dengan jumlah kelompok atau perkumpulan Dolalak yang ada. Eksistensi saat ini, kesenian Dolalak disajikan oleh penari-penari perempuan yang sebelumnya selalu disajikan oleh penari laki-laki. Saat ini tercatat kurang lebih 120 kelompok Dolalak wanita tersebar di seluruh wilayah Purworejo. Untuk itu Dolalak di Kabupaten Purworejo dijadikan sebagai kesenian unggulan.

Keberadaan Dolalak yang menjamur sangat berbeda apabila dibandingkan dengan seni pertunjukan Ching Pho Ling yang keberadaannya sangat memprihatinkan. Kesenian Ching Pho Ling yang pernah hidup di bebe rapa tempat di wilayah Purworejo seperti di Kecamatan Kaligesing, Kecamatan Bagelen, saat ini hampir punah dan satu-satunya yang masih hidup terdapat di Desa Kesawen, Kecamatan Pituruh, Kabupaten Purworejo.

Mataram Baru merupakan sebuah kekuasaan politik yang berpusat di daerah Yogyakarta, dan sejak awal abad XVII mulai menguasai Pulau Jawa. Wilayah kekuasaan Mataram merupakan lingkaran-lingkaran konsen-tris yang berpusat di keraton, tempat kediaman raja dan tempat ibukota kerajaan. Konsentris pertama disebut kutagara, ibukota kerajaan, adalah tempat pengaruh raja yang paling kuat. Konsentris kedua adalah negaragung, wilayah yang disediakan bagi lungguh (tanah yang disediakan atau dipinjam kan sebagai sarana nafkah) para kerabat dan pejabat kerajaan. Adapun konsentris ketiga disebut daerah mancanagari, jabarangkah dan pasisiran yang diperintah oleh seorang bupati kepala daerah

Konsentris kedua yang disebut daerah nagaragung biasanya di bawah wewenang seorang wadana yang disebut wadana jaba. Bagelen merupakan salah satu daerah negaragung yang tidak dipimpin oleh seorang wadana jaba tetapi oleh Demang Adipati. Untuk itu wewenang daerah Bagelen 
dikuasai oleh beberapa orang demang. Para demang ini bertugas mengurus masalah pajak serta masalah-masalah umum yang berada di kawasan wilayahnya. Para demang biasanya bertanggung-jawab kepada para Patuh, yaitu pejabat dan kerabat kerajaan yang menguasai lungguh. Para patuh sebagai golongan priyayi atau sentana merupakan orang yang menerima lungguh pada umumnya tinggal di ibukota kerajaan dan tidak mengelola sendiri tanah mereka. Mereka menyerahkan pengelolaan lungguhnya kepada para demang setempat.

Dalam suatu sistem feodal seperti Mataram yang pada masa itu belum banyak mengembangkan ekonomi uang, untuk menggaji pegawai ataupun memberi tunjangan kepada keluarga raja pada umumnya diberikan tunjangan dalam bentuk tanah, yang kemudian tanah garapan untuk nafkah tersebut disebut dengan nama tanah lungguh. Para penerima lungguh oleh para raja selanjutnya juga diberikan wewenang untuk menarik pajak atau hasil atas tanah lungguh. Tanah lungguh bagi para priyayi (pejabat kerajaan) dapat bersifat sementara, artinya hak untuk memungut pajak hanya dapat dilakukan selama si penerima lungguh menjabat. Ada pula tanah lungguh yang bersifat permanen, biasanya diberikan kepada keluarga raja, dan para sentana yang dikasihi oleh raja. Tanah lungguh yang kedua disebut tanah ganjaran atau tanah pusaka yang dapat dimiliki secara turun-temurun (Djuliati, 2000:51).

Para demang yang diberi kuasa atas tanah lungguh pada umumnya tidak mengerjakan sendiri, tetapi juga menyerahkan lagi kepada para penggarap yang disebut bekel, dan kemudian para bekel menyewakan kepada para petani yang disebut sikep. Untuk itu seorang demang juga disebut seorang kontraktor besar yang dapat mengontrakkan lungguh. Sebagian para demang juga terdapat orang Cina, meskipun jumlah mereka hanya sekitar $13 \%$ dari seluruh jumlah demang. Menurut Crawfurd, munculnya demang Cina disebabkan sebagian dari patuh terlibat hutang kepada Cina sehingga mereka menggadaikan lungguhnya yang kemudian menggantikan fungsinya sebagai demang. Setidaknya telah terjadi hegemoni oleh demang Cina terhadap para bekel (Djuliati, 2000:58).

Uraian tersebut memberikan gambaran bahwa daerah Purworejo yang merupakan wilayah Bagelen (nagaragung) mempunyai ikatan ekonomis lewat para demang tehadap para patuh yang berada di pusat kerajaan. Dari ikatan ini yang kemudian melahirkan tradisi audiensi yang disebut pisowan an, dimana para demang harus melaporkan hasil kerjanya kepada para $p a-$ tuh termasuk raja. Perjalanan para demang menuju ke pusat pemerintahan yang lebih tinggi untuk keperluan audensi, biasanya diikuti atau diiring oleh para pengawal. Dengan demikian perjalanan para demang berupa barisan atau arak-arakan yang jumlahnya tergantung dari tingkat kewibawaan seorang demang. Para pengiring juga membawa perlengkapan seperti payung, senjata seperti pedang sebagai alat pertahanan/pengamanan dan alat bunyi- 
bunyian seperti kendang dan kecrek untuk hiburan di dalam perjalanan. Mengacu pada pernyataan diawal tulisan ini bahwa seni pertunjukan di daerah Purworejo tidak lepas dari pengaruh sejarah masa lalu, Ching Pho Ling nampaknya juga merupakan salah satu wujudnya. Ikatan ekonomi demang dan patuh yang melahirkan tradisi pisowanan merupakan sumber penciptaan lahirnya bentuk seni pertunjukan seperti Ching Pho Ling.

Dalam kalangan masyarakat Jawa istilah Ching Pho Ling sangat asing, karena tidak merupakan perbendaharaan kata dalam bahasa Jawa. Berdasarkan sumber (Wiryo Pranoto dan Parto Atmojo) istilah Ching Pho Ling mempunyai arti sebagai berikut.

a. Kata Ching Pho Ling diambil dari tiga nada instrumen bende, yaitu nada 3 (lu), 2 (ro), dan 7 (pi) yang bunyinya "ning, nung, ning" dan kemudian menjadi Ching Pho Ling.

b. Kata Ching Pho Ling diartikan berasal dari gabungan nama samaran tiga orang prajurit/pengawal ki demang yang bernama Bunching, Dipo, dan Keling kemudian diambil nama bagian akhir. Ching Pho Ling tidak hanya semata-mata sebagai gambaran bentuk barisan pisowanan, namun juga sebagai barisan pengamanan. Maka dari itu properti yang digunakan Ching Pho Ling adalah berupa pedang yang dapat digunakan sebagai senjata.

c. Kata Ching Pho Ling diambil dari aspek kewibawaan barisan demang, mana kala dalam perjalanan pisowanan terdapat musuh, maka musuh akan berlari sekencang-kencangnya dan terkencing-kencing karena ketakutan, musuh akan berlari sejauh mungkin (bahasa Jawa sak pol-pol'e), sampai akhirnya jatuh terguling-guling. Apabila diambil dari akhir kata-kata tersebut, maka akan menjadi ching-pol-ling yang kemudian diucapkan Ching Pho Ling.

d. Ching Pho Ling dilihat dari bahasa China ada yang memberi arti, Ching artinya bersih atau aman, "Pho" artinya menjamin, dan "Ling" artinya perintah. Jadi kata Ching Pho Ling mempunyai arti "perintah untuk menjamin keamanan dan kejahatan".

Penjelasan yang berbeda dari narasumber tersebut disebabkan oleh sudut pandang yang berbeda. Namun demikian masyarakat setempat sebagai pendukung seni pertunjukan tidak memasalahkan dari mana Ching Pho Ling dan apa artinya, mereka tetap menyebutnya dengan nama Ching Pho Ling.

\section{FUNGSI KESENIAN CHING PHO LING}

Keberadaan kesenian dalam berbagai bentuk pada dasarnya untuk kepentingan manusia, sehingga dapat bermanfaat dalam hidupnya. Fungsi kesenian dalam masyarakat dapat bermacam-macam, yang sangat ditentukan oleh masyarakat pendukungnya.Soedarsono(1998:57) setidaknya membuat pembagian, bahwa fungsi seni (seni pertunjukan) sebagai sarana ritual, ungkap estetik dan hiburan pribadi. 
Ching Pho Ling diperkirakan lahir di beberapa desa di wilayah Purworejo pada akhir pemerintahan pejajah di Indonesia, sekitar tahun 1940-an (Depdiknas, 200:11) Desa-desa yang pernah mempunyai kesenian tersebut di antaranya adalah, Desa Kaligesing yang letaknya berada di wilayah timur dan berbatasan dengan Daerah Istimewa Yogyakarta yang pernah menjadi pusat kerajaan Mataram. Butuh nama sebuah desa sekarang menjadi nama salah satu kecamatan, letaknya di sebelah barat wilayah Purworejo, dan Desa Kesawen yang letaknya ada di bagian utara wilayah Purworejo. Pada saat ini seni pertunukan Ching Pho Ling di daerah Purworejo hampir punah dan hanya satu-satunya yang masih bertahan hidup di Desa Kesawen. Secara geografis Desa Kesawen, Kecamatan Pituruh Kabupaten Purworejo merupakan daerah pegunungan.

Disebutkan pada awal tulisan ini, sekitar abad XVIII Bagelen merupakan daerah wilayah Mataram. Untuk kelancaran jalannya pemerintahan Bagelen dibagi menjadi empat kadipaten, yaitu: Kadipaten Brengkelan yang sekarang menjadi Kecamatan Purworejo Kabupaten Purworejo, Kadipaten Semawung yang sekarang menjadi Kecamatan Kutoarjo, Kadipaten Karang Duwur, sekarang menjadi Kecamatan Kemiri dan Kecamatan Pituruh; dan Kadipaten Ngaran atau Ungaran yang sekarang menjadi Kabupaten Kebumen. Masing-masing kadipaten dipimpin oleh seorang adipati yang membawahi kademangan yang dipimpin oleh seorang demang. Secara mekanisme kerjanya seorang bawahan dalam hal ini demang selalu mengadakan audiensi atau kunjungan (pisowanan dalam Bahasa Jawa) dengan atasannya, yaitu adipati atau raja. Seorang demang sangat besar peranannya, karena sebagai pemimpin langsung masyarakat. Dalam pisowanan, demang melaporkan situasi dan kondisi masyarakat yang dipimpinnya. Pada saat demang mengadakan pisowanan kepada atasannya, biasanya selalu disertai dengan para pengiringnya. Sebagai contoh, demang Martosonto yang bertempat tinggal di wilayah Kadipaten Karang Duwe (Pituruh), sangat berwibawa dan disegani oleh demang-demang yang lain.

Keberadaan Ching Pho Ling di Desa Kesawen Kecamatan Pituruh tidak dapat dilepaskan dengan keberadaan masa lalu demang Martosonto. Kesawen dan juga Kaligesing masyarakatnya hidup dari pertanian dan tanah tegalan, sangat jauh tempat tinggalnya dari pusat hiburan yang ada di kota. Untuk itu tidak mengherankan kalau peristiwa budaya seperti pisowanan yang ada pada masa lalu dijadikan ide untuk mewujudkan bentuk pertunjukan.Masyarakat setempat mengungkapkan kegembiraan, mengungkapkan rasa keindahan dan berfungsi sebagai hiburan. Lahirlah seni pertunjukan yang bentuknya seperti barisan atau iring-iringan dan disebut Ching Pho Ling.

Dalam perkembangan selanjutnya seni tersebut berkembang fungsinya karena faktor internal dan ekternal. Pertunjukan Ching Pho Ling tidak hanya sekedar untuk hiburan sebagai pelepas kegembiraan tetapi juga untuk 
keperluan-keperluan yang terkait dengan aktivitas masyarakatnya. Faktor internal, yaitu pengaruh masyarakat setempat, menjadikan kegiatan hajadan seperti perkawinan, khitanan, kelahiran bayi, dan acara-acara hajad desa seperti bersih desa dan sejenisnya juga dilengkapi dengan pertunjukan Ching Pho Ling. Demikian pula pengaruh eksternal dengan prakarsa pemerintah setempat untuk mempergelarkan pada even tertentu seperti perayaan hari besar nasional dan penyambutan tamu daerah. Fungsi hiburan dalam berbagai guna telah terjadi karena faktor internal dan eksternal. Di Desa Kesawen sejak tahun 1957 kesenian Ching Pho Ling terwadahi dalam suatu organisasi yang diberi nama Tunggul Wulung.

\section{BENTUK DAN MAKNA PERTUNJUKAN CHING PHO LING}

Seni pertunjukan Ching Pho Ling bentuk yang nampak atau wujudnya merupakan sajian tari dan musik. Kelompok penari disajikan oleh sembilan orang laki-laki, sedang kelompok musik terdiri enam orang yang juga laki-laki. Sembilan orang penari mempunyai peran yang berbeda, yaitu satu orang penari berperan sebagai pimpinan barisan dan disebut pemayung/komendir. Delapan penari lainnya secara berpasangan berperan sebagai penari pemencak, penari pengiring, penari pembawa instrumen musik kendang buntung atau ketipung, dan penari pembawa instrumen kecrek.

Mencermati jumah penari yang terdiri dari delapan orang dengan pola lantai berbaris berpasangan dan seorang pimpinan barisan yang disebut pemayung, setidaknya merupakan gambaran atau cerminan barisan atau iring-iringan pisowanan seperti yang biasa dilakukan oleh seorang demang saat menuju pusat pemerintahan (Kadipaten). Tampilnya peran pemayung atau pimpinan barisan yang di dalam pertunjukan selalu memegang bendera, juga merupakan gambaran wibawa seorang demang. Dua orang penari yang disebut pemencak dengan membawa properti pedang juga memantapkan kesan adanya unsur pengamanan dalam barisan tersebut. Demikian pula peran penari yang membawa properti kendang dan kecrek juga sebagai gambaran agar para pengawal tidak kesepian selama perjalanan pisowanan, karena alat tersebut dapat dibunyikan sebagai hiburan saat perjalanan dirasakan melelahkan.

Sebagai karya seni, Ching Pho Ling diungkapkan melalui unsur: gerakan, suara musik, dan rupa rias busana. Tari yang ditimbulkan oleh gerak tubuh penari, merupakan unsur terkuat untuk mewujudkan bentuk pertunjukan, sedangkan unsur yang lain, yaitu suara yang ditimbulkan dari alat musik dan rupa yang dapat diamati pada busana dan properti dan bersifat penopang dalam mewujudkan bentuk fisik.

\section{Tari}

Struktur sajian Ching Pho Ling terdiri atas tiga bagian, yaitu : maju baris, mundur baris, dan perangan. Maju baris merupakan bagian pertama 
yang diawali dengan tetabuhan dan dilanjutkan dengan tampilnya para penari berbaris berpasangan yang dipimpin oleh seorang pemayung yang mem bawa bendera ke tengah arena pentas. Gerak awal yang dilakukan adalah sembahan, yang dimaknai sebagai wujud penghormatan baik kepada sang pemberi kehidupan (Tuhan) atau penonton. Setelah gerak sembahan kelompok penari berbaris dengan berbagai variasi, seperti maju-mundur, berputar, berhadapan, silang dan berganti tempat, dengan posisi tubuh berdiri dan jongkok.

Pada bagian maju baris berikutnya posisi barisan ditempat. Peran penari pemencak melakukan gerakan mengayun-ayunkan pedang ke kiri dan ke kanan, penari pengiring dengan gerak merentangkan tangan dengan memegang sampur (selendang), sedang empat penari pembawa instrumen kendang dan kecrek dengan gerak memaikan alat yang dibawanya.

Bagian kedua disebut mundur baris, para penari melakukan gerakan berbaris seperti pada bagian pertama (maju-baris) dengan berbagai variasi. Akhir dari bagian ini delapan penari membentuk satu baris berbentuk setengah lingkaran, kecuali dua orang pemencak yang mempersiapkan diri berada di tengah untuk adegan perangan.

Bagian ketiga atau terakhir disebut perangan, yaitu saat kedua orang pemencak yang membawa senjata pedang melakukan adegan perkelahian. Pada bagian perangan, selain menunjukkan keterampilan menggunakan properti pedang, juga dilakukan gerak kaki seperti menendang. Bagian perangan dirasakan sangat menarik, karena gerak sepasang penari didominasi gerakan jongkok yang terkesan seperti gerak-gerik sepasang ayam laki-laki (bahasa Jawa disebut jago) yang sedang diadu. Dalam adegan perangan terkadang juga ditampilkan gerakan lucu oleh pemencak. Selama kedua penari pemencak melakukan adegan perangan, peran pemayung tampil seba-gai penengah atau bagaikan seorang wasit yang memberikan aba-aba dengan alat peluit. Akhir dari adegan perangan ditandai dengan menyatunya kedua pemencak dan pemayung di tengah-tengah arena dan dilakukan gerakan sembahan sebagai tanda selesai pertunjukan.

Mencermati dari sajian tari, vokabuler atau pembendaharaan gerak yang ada sangat minim dan sederhana. Gerak yang hadir hanya gerak perang dengan alat pedang dan gerak kaki tendangan. Secara keseluruhan gerak yang hadir didominasi dengan gerak berbaris. Gerak berbaris ini hadir bada dua bagian yang disebut maju baris dan mundur baris. Dominasi barisan setidaknya memberikan gambaran perjalanan pisowanan yang cukup jauh.

\section{Musik}

Peranan musik dalam pertunjukan CPL memberikan suasana yang dapat mendukung gerak tari. Alat musik yang digunakan terdiri atas :

1) Tiga buah bende berlaras pelog barang bernada $3(l u), 2$ (ro), dan 7 (pi). 
2) Dua buah kendang buntung/ketipung

3) Trompet

4) Dua set kecrek

Dari penggunaan jenis-jenis instrumen tersebut, dapat diasumsikan bahwa lagu atau iringan yang disajikan sangat "sederhana" dengan menggunakan tempo yang ajeg (monotone). Kecuali pada jenis-jenis instrumen yang digunakan dalam kesenian Ching Pho Ling mempunyai fungsi yang berbedabeda, yaitu sebagai berikut.

1). Tiga buah bende yang digunakan untuk mengiringi kesenian Ching Pho Ling membentuk sebuah pola yang dibentuk oleh ketiga tabuhan bende tersebut. Tiga bende sebagai iringan kesenian Ching Pho Ling dipukul secara ajeg dan membentuk satuan pola bende. Pukulan bende berfungsi sebagai penggarap ritme atau memberikan keajegan pada irama yang disajikan. Tiap satuan pola bende tersusun dari tiga nada yang ditimbulkan dari nada 3 (lu), 2 (ro), 7 (pi) pada instrumen gamelan Jawa. Satuan pola bende disajikan terus-menerus selama berlangsungnya tari Ching Pho Ling. Satuan pola tabuhan bende dapat digambarkan sebagai berikut.

$$
\begin{aligned}
& \mathrm{p} \cdot \mathrm{p} \cdot \mathrm{p} \cdot \mathrm{p} . \\
& . \mathrm{p} . . \mathrm{p} \cdot \\
& . . .
\end{aligned}
$$

2). Kendang buntung/ketipung, tabuhan kendang buntung/ketipung (kendang hanya satu sisi berisi kulit) pada dasarnya selalu mengikuti gerak tarinya yang disebut dengan kendangan mungkus, dan juga memberikan aba-aba kepada para penari untuk melakukan peralihan posisi-posisi tertentu. Disela-sela gerak tari, tabuhan ken-dang menyajikan tabuhan pematut atau isian (suara kendang terisi tidak terasa vakum). Dengan tabuhan kendang mungkus akan dapat memberikan kemantapan gerak tarinya, seperti pada gerak perangan.

3). Trompet, selama sajian kesenian Ching Pho Ling, trompet secara terusmenerus menyajikan lagu secara "bebas" sesuai dengan tempo yang ditentukan oleh pemain kendang. Dalam hal ini penyaji trompet ditutut untuk membuat lagu dengan permainan bebas tergantung dari kemampuan penyajinya.

4). Kecrek, suatu alat penggarap ritme dengan menyajikan sebuah pola tabuhan, yang tempo sajiannya sesuai dengan tempo yang ditentukan oleh pemain kendang.

Suara-suara yang muncul dan instrumen yang digunakan pada pertunjukan Ching Pho Ling akan dapat menimbulkan suasana rame yang mendukung seluruh gerak dalam setiap adegan.

\section{Busana, Rias dan Properti}

Penggunaan busana penari dalam kesenian Ching Pho Ling sangat nampak pengaruh busana seorang sentana/priyayi Jawa. Selain itu juga 
pengaruh busana kolonial, yang sangat lekat dengan penggunaan topi yang biasa digunakan oleh para priyayi Barat. Untuk wajah, para penarinya tidak mengggunakan rias. Secara rinci penggunaan busana seluruh penari menggunakan busana sebagai berikut.

1). Tutup kepala, berupa Blangkon dikombinasi topi bangsawan Barat ber-warna hitam. Tutup kepala penari kesenian Ching Pho Ling menggunakan dua jenis, yaitu iket dan topi laken (topi zaman Belanda). Pada topi juga dihiasi dengan gombyok yang dibuat dari benang yang diletakkan di samping dan di depan. Jas tertutup berwarna hitam Baju

2). Baju digunakan untuk penutup badan bagian atas dengan model beskap berlengan panjang, dan berwarna hitam. Pada bagian bahu kiri dan kanan dipasang semacam tanda pangkat dan di bagian ujungnya diberi rumbai-rumbai benang. Pada bagian depan dipasang benang (ukuran besar) diisi gombyok berwarna merah. Selain itu menggunakan slempang berwarna merah putih yang digantungkan pada bahu. Tanda pangkat dibagian bahu baju

3). Celana hitam komprang dengan warna hitam tanpa menggunakan hiasan.

4). Kain yang diwiru dan stagen Kain, seluruh penari kesenian Ching Pho Ling kain baik yang diikatkan pada punggung.

5). Sabuk, epek timang

6). Sampur atau selendang, diikatkan pada pinggang dengan ikatan dibagian kiri. Sampur ini digunakan sebagai alat bantu memantap-kan gerak tangan. Sampur dengan warna putih atau kuning, pada kedua ujungnya diberi hiasan gombyok.

7). Selempang berwarna merah putih

8). Kacamata hitam, sebagai hiasan penutup mata atau muka, dengan warna hitam.

Properti yang dimaksud adalah alat-alat yang digunakan oleh penari sebagai kelengkapan menari ataupun untuk memantapkan gerak tari. Alat yang digunakan pada kesenian Ching Pho Ling disesuaikan dengan peran penari, yaitu sebagai: pimpinan/komendir/pemayung, pengawal dan pengamanan.

1). Pedang, dua bilah pedang yang digunakan oleh peran pengamanan yang disebut pemencak. Pedang merupakan salah satu bentuk senjata untuk melawan musuh. Sesuai dengan fungsinya penari Ching Pho Ling merupakan satu kelompok pengamanan demang dalam pisowanan. Dalam kesenian Ching Pho Ling, pedang dibawa oleh dua orang penari yang disebut $p e-$ mencak.

2). Keris juga merupakan salah satu bentuk senjata untuk melawan musuh. Keberadaan keris sebagai properti dalam kesenian Ching Pho Ling sebagai kelompok pengamanan demang dalam pisowanan. Dalam kesenian Ching Pho Ling, keris dibawa oleh para penari lainnya (selain pemencak).

3). Bendera Bendera yang dibawa oleh pemayung atau kemendir dalam pisowanan ini merupakan lambang dari seorang demang. Masing-masing demang memiliki bendera yang berbeda sebagai simbol atau identitasnya. Dalam kesenian Ching Pho Ling menggunakan dua bendera yang dibawa oleh seorang penari yang disebut pemayung atau kemendir 
Kesenian Ching Pho Ling... (Nanik Sri Prihatini)

\section{SIMPULAN}

Pisowanan dalam pertunjukan Ching Pho Ling, merupakan fenomena sosio-kultural ketika seorang demang melaporkan tugasnya di wilayah kekuasaannya. Untuk melakukan pisowanan, seorang demang diikuti oleh pengawal yang menunjukkan semangat patriotisme yang mengandung nilainilai, perjuangan, kesetiaan, kemerdekaan, kebersamaan, dan lain-lainnya

Dalam pisowanan berbentuk barisan/arak-arakan dengan membawa alat-alat senjata untuk menjaga keselamatan rombongan. Selain itu juga membawa peralatan musik sederhana yang dibunyikan untuk menghilangkan kepenatan selama perjalanan. Bentuk arak-arakan tersebut kemudian menjadi sumber ide dari lahirnya seni pertunjukan Ching Pho Ling yang ber fungsi menjadi sebuah tontonan, sehingga kesenian Ching Pho Ling di Purworejo merupakan kesenian yang dikembangkan dari budaya pisowanan yaitu arak-arakan seorang demang saat menuju ke kadipaten.

Kreativitas muncul adalah pada pengembangan gerak, iringan maupun busananya, sehingga bentuknya menjadi menarik sebagai tontonan yang berfungsi sebagai hiburan masyarakat. Keberadaan kesenian ini sangat memprihatinkan yang jumlahnya hanya tinggal satu di Kabupaten Purworejo, namun masih tetap eksis. Untuk mengantisiasi kepunahan seni itu perlu mendapatkan perhatian yang serius dari pihak pemerintah.

\section{DAFTAR RUJUKAN}

Alfian. 1985. Persepsi Masyarakat Tentang Kebudayaan. Jakarta : PT. Gramedia. Cassier, Ernst. 1987. Manusia dan Kebudayaan: Sebuah Esai Tentang Manusia. Seri Filsafat Atmajaya 6. Di Indonesiakan oleh Alois A. Nugroho. Jakarta : PT. Gramedia.

Humardani, S.D. 1979. "Kumpulan Kertas Tentang Tari”. Bahan perkuliahan pada Akademi Seni Karawitan Indonesia. Surakarta : ASKI.

Koetjaraningrat. 1984. Kebudayaan Jawa. Jakarta : PN. Balai Pustaka.

Maquet, Jacques. The Aestetic Experience an Anthropologist Looks at the Visual Art. New Haven and London : Yale University Press.

Santoso, Budhi. 1994. Kesenian dan Kebudayaan. Jurnal Seri Wiled Tahun I/Juli 1994. Surakarta : STSI Press.

Sedyawati, Edi. 1986. "Tari Sebagai Salah Satu Pernyataan Budaya". Dalam Pengantar Elementer Tari dan Beberapa Masalah Tari. Jakarta: Direktorat Kesenian Departemen Pendidikan dan Kebudayaan.

Sedyawati, Edi. 1995. "Keislaman Dalam Tari Di Indonesia". Dalam Islam dan Kesenian. Jabrohim dan Sandi Berian (penyunting). Yogyakarta : Majelis Kebudayaan Muhammadiyah Universitas Ahmad Dahlan, Lembaga Litbang PP Muhammadiyah.

Soedarsono. 1998. Seni Pertunjukan Indonesia Di Era Globalisasi. Direktorat Pendidikan Tinggi Departemen Pendidikan dan Kebudayaan.

Suroyo, Djuliati AM. 2000. Eksploitasi Kolonial Abad XIX: Kerja Wajib di Karesidenan Kedu 1800-1890. Yogyakarta: Yayasan Untuk Indonesia. 